\title{
Microbial diversity on a marble monument: a case study
}

\author{
Christine Hallmann · Jörg Rüdrich • \\ Matthias Enseleit • Thomas Friedl • \\ Michael Hoppert
}

Received: 30 April 2010/Accepted: 27 September 2010/Published online: 17 October 2010

(C) The Author(s) 2010. This article is published with open access at Springerlink.com

\begin{abstract}
In the presented case study, ascomycete fungi and green algae on a marble monument were identified by comparisons of the 18S rRNA gene sequences, which were obtained from DNA either from environmental samples or from enrichment cultures. The organisms were found to be responsible for either black or green surface coverings on different areas of the monument surface. Most fungi were related to plant-inhabiting genera, corresponding to a heavy soiling of the marble surface with honeydew. Whereas green algae of the genera Stichococcus, Chloroidium and Apatococcus were found to be dominant in all samples, isolates of two additional genera were recovered only from enrichment cultures. A reference strain of Apatococcus lobatus and an isolate of Prasiolopsis sp. were investigated with respect to putative surface adhesive structures of the cell envelope. The Prasiolopsis cell walls were covered
\end{abstract}

C. Hallmann · T. Friedl

Abt. Experimentelle Phykologie und Sammlung für Algenkulturen, Albrecht-von-Haller-Institut für

Pflanzenwissenschaften, Georg-August-Universität Göttingen,

Untere Karspüle 2, 37073 Göttingen, Germany

J. Rüdrich

Abt. Strukturgeologie und Geodynamik, Geowissenschaftliches Zentrum Göttingen, Georg-August-Universität Göttingen,

Goldschmidtstr. 1, 37077 Göttingen, Germany

\section{Enseleit · M. Hoppert ( $\square)$}

Institut für Mikrobiologie und Genetik,

Georg-August-Universität Göttingen,

Grisebachstraße 8, 37077 Göttingen, Germany

e-mail: mhopper@gwdg.de

M. Hoppert

Courant Research Centre Geobiology,

Georg-August-Universität Göttingen,

37077 Göttingen, Germany with a thin adhesive exopolysaccharide layer involved in biofilm formation.

Keywords Marble monument - Biofilm · Ascomycete fungi - Green algae $\cdot$ Cell wall $\cdot$ Exopolysaccharide

\section{Introduction}

Biodeterioration of dimension stone primarily affects material surfaces. Some endolithic organisms actively penetrate the surface and are also found in layers up to several millimeters underneath the surface (e.g., Ascaso et al. 1998; Hoppert et al. 2004a). Though several important pro- and eukaryotic organisms have already been recognized as deteriorative agents, up to now little is known about the whole microbial community (see Gorbushina 2007 and Macedo et al. 2009 for review). It must be expected that a microbial biofilm is composed of at least several dozens of species. These various organisms act in different ways on the material; a whole spectrum of deteriorative activities may be expected: from neutral (or even protective, e.g. Zuo et al. 2005) to deteriorative by penetration of the surface (Warscheid and Braams 2000; Kemmling et al. 2004). It remains difficult to assign the deteriorative activity to a certain microbial species within a biofilm. Microbial activity also varies over seasons and is influenced by rainfall, surface cleaning or input of nitrogen, phosphate and other essential compounds.

The present case study aims at the identification of organisms by two complementary approaches: analyses of 18S rDNA sequences (either directly from environmental DNA or via enrichment culture) and isolation of strains. The former approach is inevitable for elucidation of microbial diversity, since most (pro- and eukaryotic) microorganisms 
are unculturable. The latter, "classical" approach underestimates the diversity as it recovers too few of the actually present species, but has two advantages. It enables studying the physiology of organisms in pure culture and allows recovering and identification of species that are present on the surface in such low numbers of individuals that they escape DNA extraction and sequencing. These species may actually not have an important role in the biofilm at the time of sampling, but may be present as resting stages and become more abundant when the environmental conditions (e.g., insolation, humidity) change.

For the present case study, a marble sculpture, which is part of the monument "Gegendenkmal" (Fig. 1a; Hamburger Dammtordamm, created by Alfred Hrdlicka 1983-1986), was selected. The object is covered with grayish and black crusts of hitherto unknown origin as well as greenish (obviously algal) biofilms. The aim of this case study was the application of both molecular and
Fig. 1 The monument and macroscopically visible surface stains. a The monument "Gegendenkmal", created by Alfred Hrdlicka 1983-1986, located in Hamburg-Altona. The marble sculpture at the left is nearly completely covered with a dark gray/black stain. b, c Part of the sculpture "Hamburger Feuersturm" with a green (b) and dark-grayish (c) surface stain, as marked by arrows. (d, e) Thin petrographic sections perpendicular to the surface from an area as depicted in (c). Small fragments, embedded in a dark matrix, adhere to the surface (arrows, d).

Microfractures along grain boundaries, filled with a dark matrix (arrows)
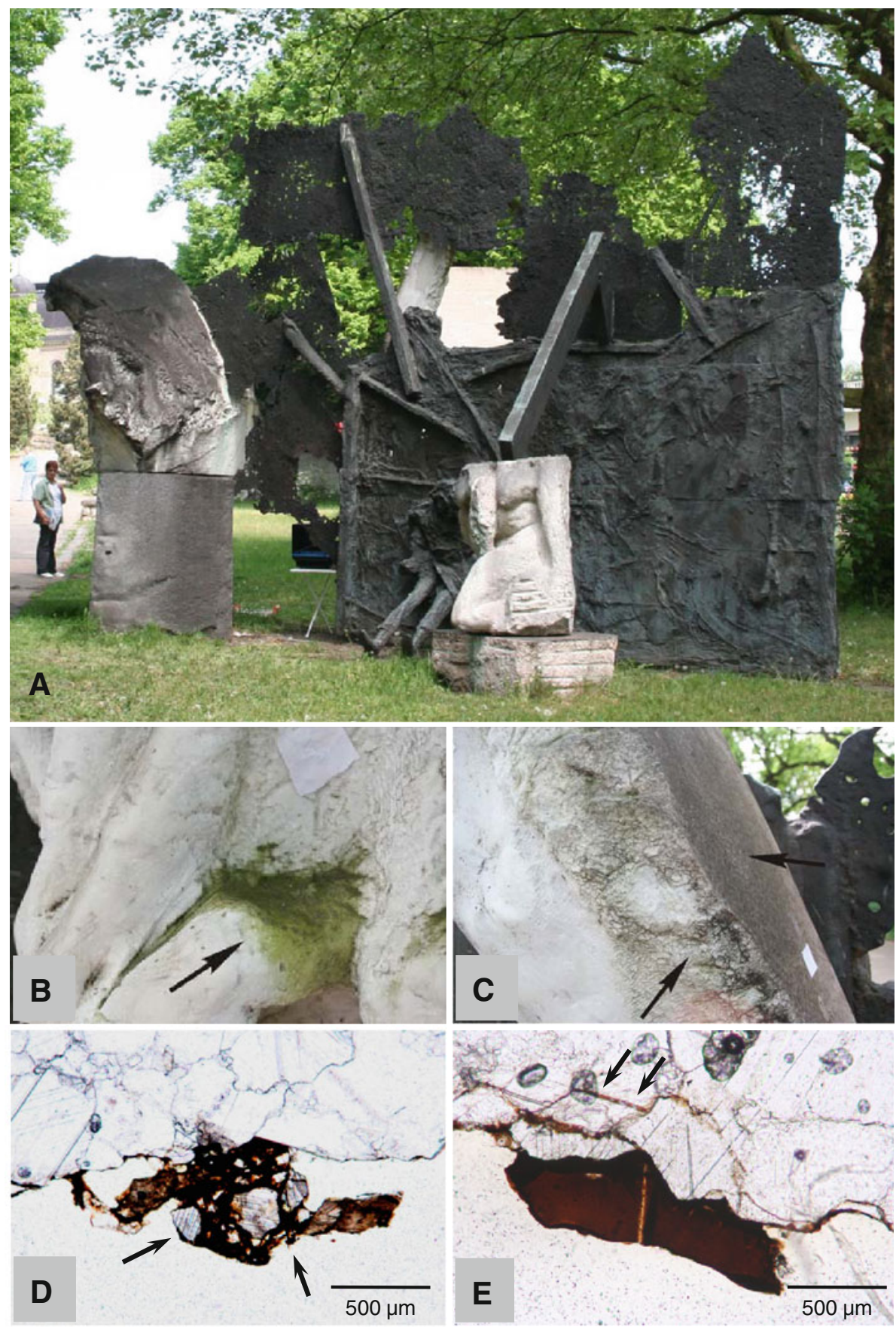
enrichment/isolation approaches to identify the organisms and to characterize cell wall features that are possibly relevant to biofilm formation. Here, we focus on green algal and fungal organisms. Members of these groups dominate the biofilm, from the first microscopic inspection of the surface, with by far highest biomasses.

\section{Materials and methods}

\section{Sampling}

The sampling site was in Hamburg Dammtor $\left(53^{\circ} 33^{\prime} 43^{\prime \prime} \mathrm{N}\right.$, $9^{\circ} 59^{\prime} 27^{\prime \prime} \mathrm{E}$ ). Samples (approximately $100 \mu \mathrm{l}$ dry volume) were collected in May 2008 from an SSW exposed part of the sculpture called "Hamburger Feuersturm". The samples were taken from two sites as depicted in Fig. 1b, c. Areas of $1 \mathrm{~cm}^{2}$ from a green surface covering (Fig. 1b, sample A) and from a dark gray/black covering (Fig. 1c, sample B), respectively, were scraped off with a sterile scalpel. The samples were stored at ambient temperature in sterile 2 -ml reaction tubes.

\section{Cultivation and isolation}

For the cultivation of microalgae, small amounts of the biofilm samples were either directly plated on agarized (1.5\%) culture medium MIEB12 (Schlösser 1994) in Petri dishes, or inoculated in $10 \mathrm{ml}$ volumes of liquid MIEB12 medium in culture tubes (enrichment culture). Cultures were kept under continuous illumination $(25 \mu$ mol photons $\mathrm{m}^{-2} \mathrm{~s}^{-1}$, white fluorescent tubes) and $18^{\circ} \mathrm{C}$ for 4 weeks. From the liquid cultures, $100 \mu \mathrm{l}$ aliquots were then plated on solid MIEB12 medium and incubated under the same conditions as for liquid media. Single colonies of different appearance were selected and transferred on fresh agar plates until unialgal cultures were obtained.

A reference stain, Apatococcus lobatus SAG 2037, was taken from the Culture Collection of Algae (SAG; GeorgAugust-Universität Göttingen, Germany) and cultured on agarized or liquid Bold's Basal medium with vitamins (Schlösser 1994).
Nucleic acid extraction, PCR, cloning and sequencing

DNA was extracted from the environmental samples as well as from the liquid cultures. All steps were performed with sterilized (autoclaved, nuclease-free) reagents. For DNA extraction, equivalents of 20-50 $\mu \mathrm{l}$ packed cell volume, either obtained from the original biofilm or from liquid cultures, were used. The biofilm samples or pelleted cells were resuspended in $100 \mu$ lysis buffer (Invisorb Spin Plant Mini Kit, Invitek, Berlin, Germany). After one volume of resuspended cells was mixed with an approximately equivalent volume of glass beads (425-600 $\mu \mathrm{m}$ diameter; acid-washed beads, Sigma-Aldrich, St. Louis, MO, USA) and vortexed briefly, the cells were mechanically disrupted by shaking in a Minibeadbeater (Biospec, Bartlesville, OK, USA) in several intervals of $30 \mathrm{~s}$ and one interval of $50 \mathrm{~s}$ at $5,000 \mathrm{rpm}$. DNA was then extracted with the Invisorb Spin Plant Mini Kit (Invitek, Berlin, Germany) in the extraction buffers, following the manufacturer's instructions. Results were checked on a $1 \%(\mathrm{w} / \mathrm{v})$ agarose gel. Isolated DNA was stored at $-20^{\circ} \mathrm{C}$ until further processing. The eukaryote-specific primer combinations NS1+18L and NS1+LR 1850 were used (Table 1 ) to amplify the $18 \mathrm{~S}$ and the $18 \mathrm{~S}$ with adjacent ITS-1/5.8S/ITS-2 regions of rDNA, respectively.

About $30 \mathrm{ng}$ of the extracted DNA was used as template. The amplification reaction mixture $(50 \mu \mathrm{l})$ contained each deoxynucleotide triphosphate at a concentration of $0.1 \mathrm{mM}, 5 \mu \mathrm{l}$ of tenfold concentrated reaction buffer, $2 \mathrm{mM} \mathrm{MgCl} 2,0.2 \mu \mathrm{M}$ primers, $2 \mathrm{U}$ of Taq DNA polymerase (reagents and manufacturer's protocol: Bioline, Luckenwalde, Germany) and 4\% (v/v) dimethyl sulfoxide (DMSO)-solution. Polymerase chain reaction was carried out on a PTC 200 thermocycler (MJ Research, Waltham, MA, USA) using the following program for the primer pair $\mathrm{NS} 1+\mathrm{LR} 1850$ : initial denaturation at $95^{\circ} \mathrm{C}$ for $5 \mathrm{~min}$, followed by 33 cycles of denaturation at $94^{\circ} \mathrm{C}$ for $40 \mathrm{~s}$, annealing at $52^{\circ} \mathrm{C}$ for $90 \mathrm{~s}$, extension at $72^{\circ} \mathrm{C}$ for $90 \mathrm{~s}$, followed by 6 cycles of denaturation at $94^{\circ} \mathrm{C}$ and final extension at $72^{\circ} \mathrm{C}$ for $2 \mathrm{~min}$. For the primer pair NS1+18L, denaturation was for $1 \mathrm{~min}$, annealing for $45 \mathrm{~s}$, extension for $3 \mathrm{~min}$, the additional 6 cycles were omitted and final
Table 1 Primers used in this study

\begin{tabular}{lll}
\hline Primer & Sequence $5^{\prime}-3^{\prime}$ & Reference \\
\hline NS1 (forward) & GTAGTCATATGCTTGTCT & White et al. (1990) \\
18L (reverse) & CACCTACGGAAACCTTGTTACGACTT & Hamby et al. (1988) \\
LR1850 (reverse) & CCTCACGGTACTTGTTC & Friedl (1996) \\
M13F (forward) & TGTAAAACGACGGCCAGT & Invitrogen \\
M13R (reverse) & GGCAGGAAACAGCTATGACC & Invitrogen \\
895R (sequencing primer) & GAGGTGAAATTCTTGGATTT & SAG \\
\hline
\end{tabular}


extension was for $7 \mathrm{~min}$. The PCR products were purified using the Invisorb Spin PCRapid Kit (Invitek, Berlin, Germany). Aliquots $(2 \mu \mathrm{l})$ of purified amplicons were analyzed by electrophoresis on a $1 \%(\mathrm{w} / \mathrm{v})$ agarose gel. Cloning of the PCR product was performed with the TOPO TA cloning kit (Invitrogen, Carlsbad, CA, USA) and the pCR2.1-TOPO vector. Ligations were transformed into competent cells of Escherichia coli TOP 10, as supplied by the manufacturer. In the plasmid screening, white $E$. coli colonies containing correct DNA insertions were identified by direct amplification of the inserted DNA fragment with a vector-specific primer set M13F/M13R (Table 1).

Clones were cultivated overnight in LidBac reaction tubes (Qiagen, Hilden, Germany) with $1 \mathrm{ml} \mathrm{LB}$ medium containing $100 \mu \mathrm{g}$ ampicillin. Plasmid DNA was prepared from the clones with a NucleoSpin-Plasmid kit (Macherey and Nagel, Düren, Germany) following the manufacturer's instructions.

Sequencing reactions were performed with a Dye Terminator Cycle Sequencing v3.1 kit (Applied Biosystems, Darmstadt, Germany) and an ABI Prism 3100 (Applied Biosystems) automated sequencer. All clones were sequenced with the $18 \mathrm{~S}$ sequencing primer $895 \mathrm{R}$ (Table 1) resulting in about 600 bp sequences. Sequences were processed using the sequence analysis program SeqAssem (Sequentix, Klein Raden, Germany) and manually aligned using the program BioEdit v7.0.5.3 (Meusnier et al. 2008). The final sequences were compared by BLASTn analysis [National Center for Biotechnology Information (NCBI), http://www.ncbi.nlm.nih.gov].

\section{Light and electron microscopy}

For fluorescence light microscopy, cells taken from unialgal or pure cultures were marked with concanavalin A, coupled to fluorescein isothiocyanate (Con A-FITC; Sigma-Aldrich). The dye was applied in $50 \mathrm{mM}$ potassium phosphate buffer, supplemented with $10 \mu \mathrm{M}$ magnesium chloride and $10 \mu \mathrm{M}$ calcium chloride at a dilution of $1 /$ 1,000 of the original stock solution. The sample was inspected under a fluorescence light microscope (Axioscope, Zeiss, Göttingen, Germany; excitation wavelength $495 \mathrm{~nm}$, emission wavelength $517 \mathrm{~nm}$, Zeiss filter set 09).

Petrographic thin sections of approximately $30 \mu \mathrm{m}$ in thickness were performed according to established procedures (Adams et al. 1984) and visualized by standard bright field microscopy.

For electron microscopy, cells from unialgal or pure cultures were harvested by centrifugation at $10,000 \times g$, resuspended in $50 \mathrm{mM}$ potassium phosphate buffer, chemically fixed in $0.5 \%(\mathrm{w} / \mathrm{v})$ formaldehyde and $0.3 \%(\mathrm{w} /$ v) glutaraldehyde solution for $90 \mathrm{~min}$ at $0^{\circ} \mathrm{C}$, dehydrated in a graded methanol series and embedded in Lowicryl $\mathrm{K} 4 \mathrm{M}$ resin (Roth et al. 1981; Hoppert and Holzenburg 1998). Resin sections of 80-100 nm thickness were cut with glass knives. Localization studies were performed with the lectin concanavalin A (Sigma-Aldrich), coupled to colloidal gold (Con A-Gold), as already described (Kämper et al. 2004). In brief, sections were incubated on drops of dilutions (1/ $10,1 / 100,1 / 1,000)$ of the Con A-gold marker for $90 \mathrm{~min}$, then washed for 5 min per step for three times on drops of PBS containing $0.01 \%(\mathrm{v} / \mathrm{v})$ Tween 20. Finally, the sections were stained with $0.5 \%(\mathrm{w} / \mathrm{v})$ phosphotungstic acid, $\mathrm{pH} 7.0$, for $3 \mathrm{~min}$. Electron microscopy was performed in a Zeiss EM 902 transmission electron microscope (Zeiss SMT, Oberkochen, Germany), equipped with a $1 \mathrm{~K}$ digital camera, at $80 \mathrm{kV}$ acceleration voltage and at calibrated magnifications.

\section{Results}

Diversity of fungal and algal organisms

The monument "Gegendenkmal" consists of several bronze and marble sculptures. In this study, the sculpture "Hamburger Feuersturm", made of Carrara marble, was under investigation. The sculpture showed a mixture of greenish and grayish/black stains (Fig. 1), as well as green layers on the fracture surfaces of chips and scales (cf. Warscheid and Braams 2000). The sculpture was manufactured from Bianco Carrara C, a pure calcite marble, as determined by X-ray diffractometry (data not shown).

Thin petrographic sections, perpendicular to the surface, show open grain boundaries between the calcite crystals in the marble microstructure (Fig. 1d, e), which illustrates the increased porosity and a slight sugar-like crumbling of the marble surface. The grayish stain, mainly on the top parts of the marble sculptures, was the most obvious feature (Fig. 1a, c). In petrographic sections, the stain appears to be homogeneous, slightly red-brown and translucent. It encloses crystals on the marble surface (Fig. 1d) and infiltrates the surface along open grain boundaries (Fig. 1e). Though the cause of this heavy soiling could not be identified, it was observed that honeydew covered the sculptures in the affected areas. The honeydew was dripping off a plane tree canopy (Platanus $\times$ hispanica), placed directly above the monument, as well as a lime tree canopy (Tilia platyphyllos) nearby. Another obvious feature was represented by green stains of algal biofilms, primarily growing in cavities, where water cannot drain off fast. To investigate the participation of microorganisms in these surface coverings, material from approximately $1 \mathrm{~cm}^{2}$ surface was used for further processing. Green layers under scales were not enclosed in this study, because they 
represented just a small fraction of the (putatively) biogenic stains. Sample A was taken from a green algal biofilm (Fig. 1b) and sample B from the black covering as depicted in Fig. 1c.

The samples were first inspected by light microscopy to verify the presence of dominant species. Actually, green algal (sample A) and fungal (sample B) morphotypes dominated the microbial biomass of the biofilm (Fig. 2a, b). Thus, our further studies aimed at the identification of the species from both these groups. Most of the algal morphotypes correspond to Apatococcus and Chloroidium ellipsoideum (Darienko et al. 2010). No stratification of the biofilms could be observed: filamentous fungi (if present) and green algae were interwoven in a homogeneous surface covering. In enrichment cultures, inoculated with samples from the original biofilm, besides Chloroidium-morphotypes, rod-shaped Stichococcus-like cells dominated (Fig. 2c). Unialgal cultures could be obtained for some of the dominant Stichococcus and Apatococcus like morphotypes (cf. Fig. 3a, b). In addition, a xanthophyte alga (Fig. 3c) and a Prasiolopsis (Pseudopleurococcus)-like morphotype (Fig. 3d; see below) could be isolated.

Sequences obtained from clone libraries of environmental DNA samples also recovered Stichococcus ( $S$. mirabilis related) and Apatococcus, however, failed to detect Prasiolopsis and xanthophytes (Table 2). Instead, Trebouxia (a frequent lichen alga) was found. Besides the dominating Stichococcus spp. algae, a variety of ascomycete fungi was found exclusively in sample B. Among the fungi, members of the ascomycete genera, Batcheloromyces, Teratosphaeria, Thelocarpon and Sarcinomyces, were recovered, each with more than one clone. Batcheloromyces, Teratosphaeria and Guignardia are known as plantinhabiting ascomycetes (Crous et al. 2004). Thelocarpon represents a lichenicolous ascomycete genus. The genus Sarcinomyces describes black yeasts from various habitats (Cooke 1961).

The clone libraries from the enrichment cultures showed lower diversities. Stichoccoccus bacillaris-like algae were dominant (Table 3) and no fungal organisms could be detected. It has to be stated, nevertheless, that not all organisms could be assessed by the clone bank analysis. The observed xanthophycean algae as well as Prasiolopsis, which were observed in the cultures, were not recovered by clone libraries from environmental samples. The identity of the Prasiolopsis genus was confirmed by $18 \mathrm{~S}$ rDNA sequencing of preparations obtained from unialgal cultures.

\section{Cell surface features of selected species}

The branched filamentous Prasiolopsis was selected for further morphological studies. The organism was
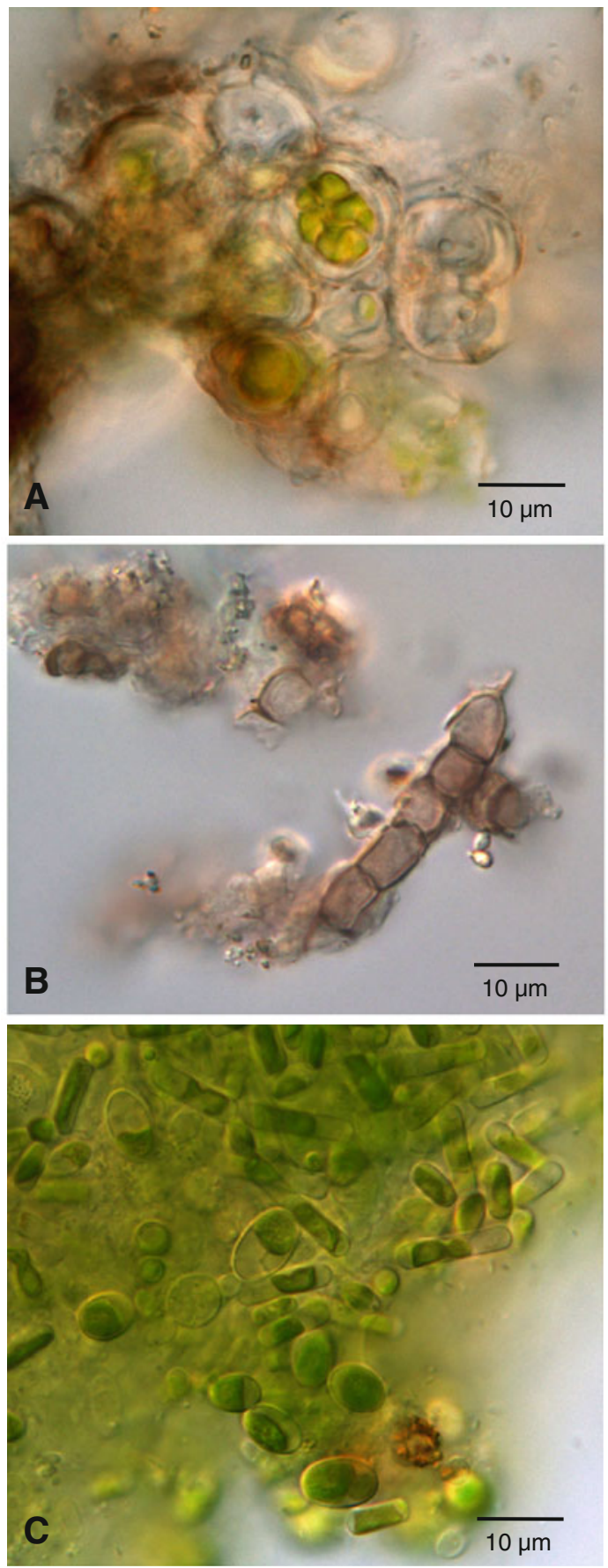

Fig. 2 Microscopic analysis of environmental samples and enrichment cultures. a Agglomeration of coccoid algae taken from the marble surface. b Ascomycete fungal morphotype (putative conidial fragment) taken from the surface. c Unicellular green algal morphotypes in an enrichment culture

compared with a contrasting morphotype, represented by Apatococcus lobatus SAG 2037, which forms irregular packages consisting of several dozens of cells (Figs. 3b, 4a). These algae represent the most different biofilm morphotypes in this study, i.e., unicellular coccoid and 
Fig. 3 Morphotypes of investigated algal stains. a Stichococcus sp., b Apatococcus lobatus SAG 2037, c a xanthophycean algae, d Prasiolopsis sp.
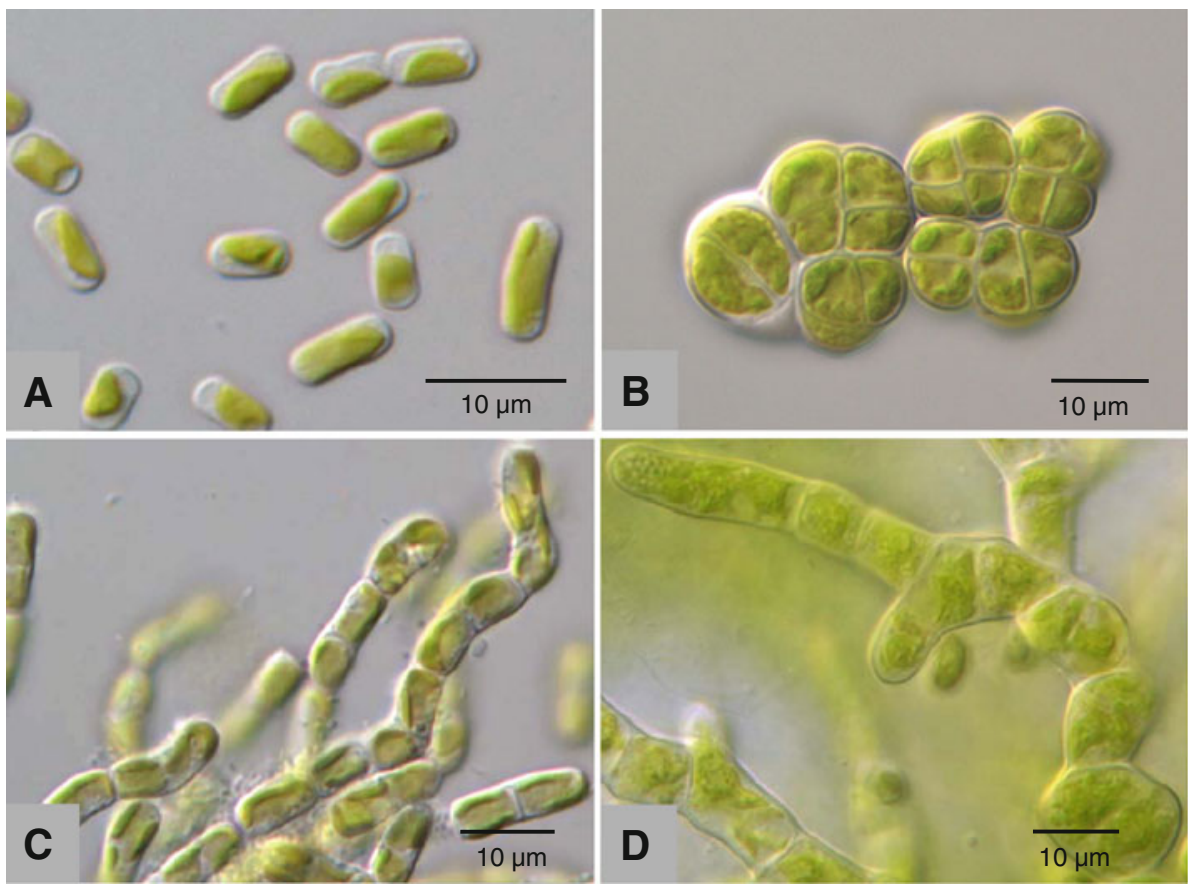

branched filamentous (Figs. 3b, d, 4). With respect to biofilm formation, we were particularly interested in cell surface features that are involved in adhesion, such as secreted polysaccharides (e.g., Tsuneda et al. 2003). In search of such features, polysaccharide-specific stains were applied (Figs. 4, 5). In ultrathin sections of the algal cell walls, a thin irregular layer on the surface of the Prasiolopsis cell walls was observed (Fig. 4e, arrows), whereas the cell walls of Apatococcus did not show any additional layers (Fig. 4b). To detect possible heteropolysaccharides of the cell envelope, staining with labeled concanavalin A (Con A) was applied. In both algae, the cell periphery showed certain fluorescence signals (Fig. 4a, d). Localization with Con A-gold revealed, at electron microscopic resolution, a scattered distribution of gold markers over the whole cell wall section of Apatococcus (Fig. 4c), and a very distinct marked outer layer in Prasiolopsis (Fig. 4f). This accounts for a thin layer of exopolysaccharides (EP) in Prasiolopsis. This layer appears to be involved in adhesion of separate Prasiolopsis filaments as depicted in Fig. 5. Here, the cells adhere to each other by the thin EP layer (Fig. 5b).

\section{Discussion}

Our case study aims at the elucidation of surface stains caused by microbial impact. Besides general climatic features (such as precipitation, insolation or temperature), especially local factors (the effect of honeydew) determine the biofilm formation and its taxonomic composition.
The sampling site in Hamburg experiences an oceanic climate, with average annual precipitation of $774 \mathrm{~mm}$ and an average annual temperature of $9^{\circ} \mathrm{C}$. The average temperature in May 2008 , however, was approximately $15^{\circ} \mathrm{C}\left(3^{\circ} \mathrm{C}\right.$ higher than the long-time average for May). Precipitation was just about $25 \%$ of the long-time average for May (54 mm) (data were taken from Deutscher Wetterdienst, Offenbach). Thus, the biofilms developed under relatively warm and dry conditions. It is, however, still difficult to draw a relation between climate and the detected organisms: most of the detected species are distributed worldwide, with seemingly broad ecological amplitude, a finding typical for most microorganisms known so far (c.f. Finlay and Esteban, 2004). Thus, a "biogeography" of microbial species is yet to be revealed (Hedlund and Staley 2004; Martiny et al. 2006). From the data presented here, however, one feature is obvious. Molecular analysis of $18 \mathrm{~S}$ rDNA clone libraries from sample B revealed a high diversity of ascomycete fungi, as compared with sample A, dominated by algae (Table 2). Sample B was taken from an area intensively soiled by honeydew. Sample A was taken from a cavity (Fig. 1b), where, due to the complex geometry of the sculpture, immediate soiling with honeydew can be excluded. Here, the photoautotrophic algae are dominant. These cavities will retain rainwater for longer time than the exposed surfaces. Rainwater may also transport some dissolved carbohydrates (see below) from the honeydew layer to the cavity but, in toto, the conditions are obviously more favorable for algae than for ascomycetes.

Intriguingly, among the most frequently found clones from sample $\mathrm{B}$, the closest related species are known as 
plant associated or plant pathogenic. Batcheloromyces proteae and Teratospora (Mycosphaerella) microspora are (opportunistic) pathogens, which are causative agents of black leaf spot disease (Crous et al. 2004). Also Spencermartinsia sp. is a plant-inhabiting fungus and an opportunistic phytopathogen (Phillips et al. 2008), as well as

Table 2 18S rDNA analysis of clones obtained from environmental samples

\begin{tabular}{|c|c|c|c|}
\hline \multirow[t]{2}{*}{ Closest relative species } & \multicolumn{2}{|c|}{ Number of clones } & \multirow{2}{*}{$\begin{array}{l}\% \text { sequence } \\
\text { similarity to } \\
\text { closest relative } \\
\text { species }\end{array}$} \\
\hline & (sample A) & (sample B) & \\
\hline \multicolumn{4}{|l|}{ Algae } \\
\hline Stichococcus mirabilis & 10 & 24 & $98-99$ \\
\hline Uncultured Trebouxia sp. & 1 & 1 & $97-98$ \\
\hline Apatococcus sp. & 2 & - & $98-99$ \\
\hline Stichococcus sp. & 1 & 1 & 99 \\
\hline Stichococcus jenerensis & 1 & - & 98 \\
\hline Chloroidium mirabilis & 1 & - & 98 \\
\hline Stichococcus bacillaris & 1 & - & 96 \\
\hline \multicolumn{4}{|l|}{ Acomycete fungi } \\
\hline Batcheloromyces proteae & & 5 & $98-99$ \\
\hline $\begin{array}{l}\text { Teratosphaeria } \\
\text { microspora }\end{array}$ & & 3 & 96 \\
\hline Thelocarpon laureri & & 3 & $95-97$ \\
\hline Sarcinomyces sp. & & 2 & $93-97$ \\
\hline Guignardia mangiferae & & 1 & 100 \\
\hline $\begin{array}{l}\text { Phaeoramularia } \\
\text { hachijoensis }\end{array}$ & & 1 & 98 \\
\hline Phialophora sp. & & 1 & 98 \\
\hline Conisporium perforans & & 1 & 97 \\
\hline Spencermartinsia sp. & & 1 & 97 \\
\hline Xenomeris raetica & & 1 & 97 \\
\hline Symbiotaphrina kochii & & 1 & 97 \\
\hline $\begin{array}{l}\text { Mycocalicium } \\
\text { polyporaeum }\end{array}$ & & 1 & 96 \\
\hline Aureobasidium pullulans & & 1 & 95 \\
\hline Harpidium rutilans & & 1 & 95 \\
\hline $\begin{array}{l}\text { Pseudofusicoccum } \\
\text { stromaticum }\end{array}$ & & 1 & 93 \\
\hline
\end{tabular}

Xenomeris raetica. Members of the genus Xenomeris are possibly infectious agents of tree canker (Jasalavich et al. 2000). Phialophora comprises plant- and human-pathogenic species, as well as saprophytic, wood-decaying nonpathogens (Abliz et al. 2004). Guignardia magniferae is an endophytic, but not necessarily a plant-pathogenic, fungus (Suryanarayanan et al. 2004). Undoubtedly, the plantassociated fungi were transferred from the tree canopies to the marble surface, by honeydew droplets. Honeydew is a carbohydrate-rich secretion mainly consisting of monosaccharides, as well as the trisaccharide melezitose $(O-\alpha-\mathrm{D}-$ glucopyranosyl- $(\rightarrow 3)-O$ - $\beta$-D-fructofuranosyl- $(2 \rightarrow)-\alpha$-Dglucopyranoside), which can be easily used by fungi and other microorganisms as growth substrates (Fischer et al. 2002). The concentration of amino acids in honeydew is relatively low (in the range of 3-20 nmol/ $\mu \mathrm{l}$ ), which is a growth-limiting factor. However, the overall nitrogen input (also from atmospheric sources) is sufficient for the development of plant-associated fungi: such as other oligotrophic fungi, they are well adapted to the plant biomass with wide $\mathrm{C} / \mathrm{N}$ ratios (Wainright et al. 1993 and references therein).

Massive colonization of black-pigmented ascomycete fungi ("black fungi", Dematiaceae) has been frequently observed in conjunction with honeydew coverings of surfaces (e.g., Crozier 1981; Gerson 1975). On leaves of affected plants, colonization is referred to as sooty mold. Sooty mold is also a common disease on plane and linden trees (Hughes 1976). Among other genera, also Aureobasidium species have been described for the normal phyllosphere as well as for sooty mold. Aureobasidium is not just a plant-associated ascomycete. Members of this genus, as well as the detected Sarcinomyces, frequently occur on rock and dimension stone surfaces (Simonovicova et al. 2004; Wollenzien et al. 1997). Organisms of this group have been identified as deteriorative rock-dwelling agents on natural and dimension stone (Gorbushina et al. 1993; Gorbushina and Krumbein 2000). The black pigmentation is attributed to the ultraviolet-protective melanin (Bell and Wheeler 1986). In fungi, melanin is synthesized via different pathways, frequently from acetate via 1, 8-dihydroxynaphthalene as intermediate. The resulting phenolic polymer is deposited in- or outside the fungal cell wall
Table 3 18S rDNA analysis of clones obtained from enrichment cultures

\begin{tabular}{llll}
\hline Closest relative species & \multicolumn{2}{l}{ Number of clones } & $\begin{array}{l}\text { \% sequence similarity } \\
\text { to closest relative species }\end{array}$ \\
\cline { 2 - 3 } & (sample A) & (sample B) & \\
\hline Algae & 21 & 12 & $98-100$ \\
$\quad$ Stichococcus bacillaris & 4 & 2 & $98-100$ \\
Chloroidium ellipsoideum & 3 & 1 & 99 \\
Chloroidium angustoellipsoideum & - & 3 & 98 \\
Stichococcus mirabilis & 2 & - & 100 \\
Stichococcus deasonii & & & \\
\hline
\end{tabular}


Fig. 4 Light and electron microscopy of lectin-labeled cells. a Fluorescence light microscopy of a Con A-FITClabeled Apatococcus aggregate. b Ultrathin section of an Apatococcus cell wall. c Con Agold labeled ultrathin section of an Apatococcus cell wall. Dark dots represent the colloidal gold marker. d Fluorescence light microscopy of Con A-FITClabeled Prasiolopsis filaments. The inset shows a typical aggregate (phase contrast image). e Ultrathin section of a Prasiolopsis cell wall. The thin exopolysaccharide layer is marked by arrows. f Con A gold-labeled ultrathin section of a Prasiolopsis cell wall
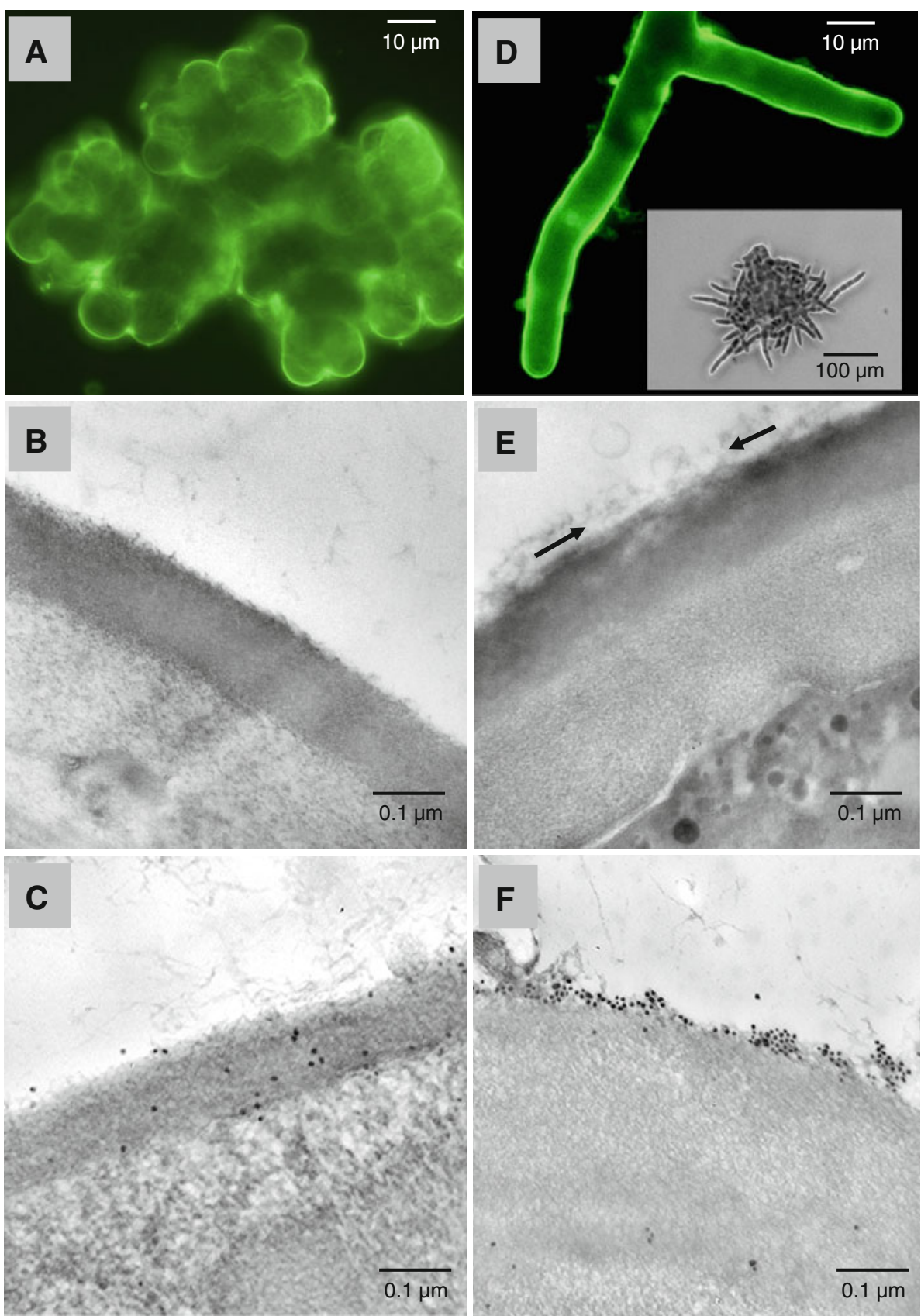

(Bartnicki-Garcia 1968). Hence, the dark stain is difficult to handle. Though superficial soiling, even black gypsum crusts on top of a surface are removable with mild chemical or biological agents (e.g., Polo et al. 2010), the organisms and stains may also penetrate the genuine marble surface (cf. Fig. 1e). When these cell wall remnants cannot be removed mechanically, or by application of mild detergents, rather harsh chemical treatment, e.g., with hydrogen peroxide as strong oxidant, is necessary to destroy the melanin (Korytowski and Sarna 1990).

According to the clone library data, the group of plantassociated ascomycetes dominates over the rock-inhabiting genera. Though even sequencing clone libraries to saturation (which was not done here) does not reflect the real species diversity exactly (Jeon et al. 2008), we find in our case study a clear tendency for the presence of "allochthonous", not genuinely rock-inhabiting fungi. The organisms grow in the honeydew cover on the marble sculpture, whereas the "autochthonous" organisms do not benefit from the honeydew in the same way.

In contrast, the algal species of the genus Stichococcus are typical colonizers of stone surfaces (cf. e.g., Michailyuk 2008). It is noticeable that, though the algae are photoautotrophic, they may also benefit from external organic 

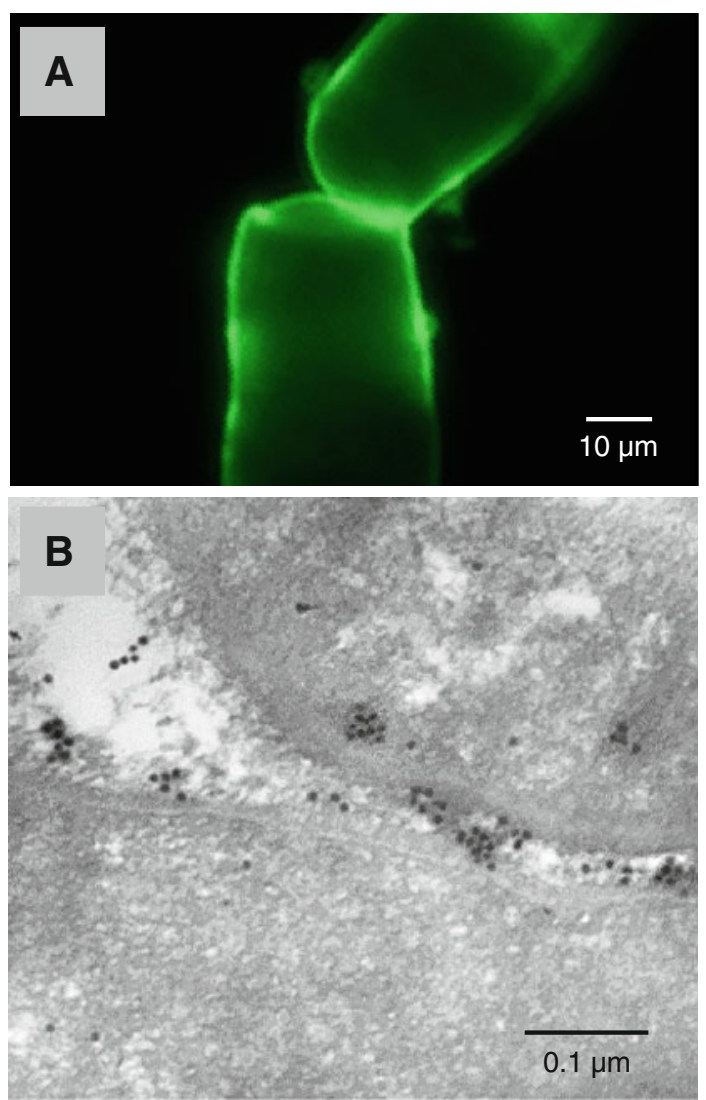

Fig. 5 Agglutination of Prasiolopsis filaments. a Fluorescence light microscopy of two attached filaments. b The same situation as depicted in a visualized by electron microscopy. Two attached filaments agglutinate via a thin exopolysaccharide layer, labeled with the Con A-gold maker

nutrients, especially from sucrose (e.g., Samejima and Myers 1958). Growth enhancement by carbohydrates has also been shown for Stichococcus mirabilis (Mattox and Bold 1962). This may be one reason for the abundance of this algal species in a biofilm dominated by diverse fungi. Generally, the most abundant algal species were small unicellular morphotypes, known as pioneer organisms (e.g., Garty 1992; Bellinzoni et al. 2003). Besides these organisms, others must be present in very low numbers of individuals, as a "seed bank" inside the biofilm (Table 3). Hence, their sequences were not present in the clone libraries, derived from environmental DNA. They will become important when environmental conditions change (which is, in fact, the case during enrichment of organisms from biofilm samples in a liquid culture). Some species may even not be detected in clone libraries of enrichment cultures, such as, in our example, Prasiolopsis sp., a green alga that could be obtained in unialgal culture. Prasiolopsis is a peculiar subaerial alga living on rock or tree bark with multiseriate filamentous or pseudo-parenchymatous thalli (Karsten et al. 2005). Branched filaments are well adapted to those environments where tiny paths and small cavities, as well as impassable (crystalline) particles form a more or less solid substratum (e.g., Ritz and Young 2004). Moreover, the algal exopolysaccharides (EP) facilitate the attachment to a surface as well as agglutination of organisms to each other. Up to now, mainly thick algal EP layers in aquatic biofilms have been described (see Sutherland 2001 for review), where green algae and cyanobacteria are covered with a thick polysaccharide layer. It is also known that EP stabilizes terrestrial (soil) biofilms such as microbiotic soil crusts (Hoppert et al. 2004b; Bowker et al. 2008). The role of EP on dry, solid surfaces is much less known, though it is obvious that the organisms also produce these extracellular polymers. For detection of specific oligosaccharides in EP, marker techniques based on the binding of lectins to certain oligosaccharides stretches are used. The lectin concanavalin A binds to oligomannose-type $\mathrm{N}$-glycans. These motifs are common in cell wall polysaccharides and especially in EP of a variety of organisms, including cyanobacteria and eukaryotic algae (Mehta and Vaidya 1978; Tien et al. 2005).

The Apatococcus strain does not show a layer adjacent to the cell wall, though the rigid wall itself exhibits a dispersed labeling (Fig. 4c). Heteropolysaccharides of different proportions are common in algal cell walls (Takeda and Hirokawa 1984; Okuda 2002) and can also be expected for Apatococcus. Prasiolopsis, in contrast, forms a thin layer of just several tens of $\mathrm{nm}$ in thickness, distinctively labeled with the concanavalin A-lectin (Fig. 4e, f). Compared with other EP layers from eukaryotic algae (e.g., Leppard 1995), Prasiolopsis exhibits even in the hydrated state only a thin EPS coating. This layer may not have more than a gluing function. Up to now, there are no data concerning the interaction between the filaments and a material surface, but it is obvious that single filaments agglutinate via the thin EP layer (Fig. 5). This may be an important feature for the formation of an interwoven meshwork of branched filaments.

\section{Conclusion}

In our case study, we examined the microbial diversity on a monument contaminated by honeydew. Remarkably, typical rock-inhabiting fungi appear to be less relevant than plant-inhabiting fungal microorganisms. Less contaminated areas of the sculpture exhibited typical green algal biofilms. Among the algae, unicellular Stichococcus-, Chloroidium- and Apatococcus-related strains were dominant in environmental samples and in enrichment cultures. Other algae, like Prasiolopsis, could also be isolated.

These results show the high relevance of an external carbon source (honeydew) for surface colonization by ascomycete fungi and, hence, formation of a dark-stained 
biofilm layer. The dark surface stain can only be avoided by removal of the carbon source, e.g., the honeydew, which may be achieved by suitable pest control. Also, an appropriate shaping of the canopy may lead, in this case, to an effect: parts of the sculptures are presently positioned in a way that they are placed rather under the periphery of the tree canopies. Thinning of the crown may not completely prevent, but reduce, the impact of down-dripping honeydew.

Acknowledgments The support of Mrs Ruth Hauer (Denkmalschutzamt Hamburg) during the field work is gratefully acknowledged.

Open Access This article is distributed under the terms of the Creative Commons Attribution Noncommercial License which permits any noncommercial use, distribution, and reproduction in any medium, provided the original author(s) and source are credited.

\section{References}

Abliz P, Fukushima K, Takizawa K, Nishimura K (2004) Identification of pathogenic dematiaceous fungi and related taxa based on large subunit ribosomal DNA D1/D2 domain sequence analysis. FEMS Immunol Med Microbiol 40:41-49

Adams AE, MacKenzie WS, Guilford C (1984) Atlas of sedimentary rocks under the microscope. Longman Publ. Group, New York

Ascaso C, Wierzchos J, Castello R (1998) Study of the biogenic weathering of calcareous litharenite stones caused by lichen and endolithic microorganisms. Intl Biodeterior Biodegrad 42:29-38

Bartnicki-Garcia S (1968) Cell wall chemistry, morphogenesis and taxonomy of fungi. Annu Rev Microbiol 22:87-108

Bell AA, Wheeler MH (1986) Biosynthesis and functions of fungal melanins. Annu Rev Phytopathol 24:411-451

Bellinzoni AM, Caneva G, Ricci S (2003) Ecological trends in travertine colonisation by pioneer algae and plant communities. Intl Biodet Biodegrad 51:203-210

Bowker MAG, Koch W, Belnap J, Johnson NC (2008) Nutrient availability affects pigment production but not growth in lichens of biological soil crusts. Soil Biol Biochem 40:2819-2826

Cooke WB (1961) A taxonomic study in the "black yeasts". Mycopathologia 17:1-43

Crous PW, Denman S, Taylor JE, Swart L, Palm ME (2004) Cultivation and diseases of Proteaceae: Leucadendron, Leucospermum and Protea. CBS Biodiv Ser 2:1-226

Crozier L (1981) Beech honeydew: forest produce. New Zeal J Forest 26:200-209

Darienko T, Gustavs L, Mudimu O, Rad Menendez C, Schumann R, Karsten U, Friedl T, Pröschold T (2010) Chloroidium, a common terrestrial coccoid green alga previously assigned to Chlorella (Trebouxiophyceae, Chlorophyta). Eur J Phycol 45:1469-4433

Finlay BJ, Esteban GF (2004) Ubiquitous dispersal of free-living microorganisms. In: Bull AT (ed) Microbial diversity and bioprospecting. ASM Press, Washington, pp 216-224

Fischer MK, Völkl W, Schopf R, Hoffmann KH (2002) Age-specific patterns in honeydew production and honeydew composition in the aphid Metopeurum fuscoviride: implications for ant-attendance. J Insect Physiol 48:319-326

Friedl T (1996) Evolution of the polyphyletic genus Pleurastrum (Chlorophyta): inference from nuclear-encoded ribosomal DNA sequences and motile cell ultrastructure. Phycologia 35:456-469

Garty J (1992) The postfire recovery of rock-inhabiting algae, microfungi and lichens. Can J Bot 70:310-312
Gerson U (1975) A soft scale as an urban pest. Isr J Entomol 10:25-28

Gorbushina AA (2007) Life on the rocks. Environ Microbiol 9:613-631

Gorbushina AA, Krumbein WE (2000) Rock dwelling fungal communities: diversity of life styles and colony structure. In: Seckbach J (ed) Journey to diverse microbial worlds. Kluwer, Amsterdam, pp 317-334

Gorbushina AA, Krumbein WE, Hamman CH, Panina L, Soukharjevski S, Wollenzien U (1993) Role of black fungi in colour change and biodeterioration of antique marbles. Geomicrobiol $\mathrm{J}$ 11:205-221

Hamby RK, Sim LE, Zimmer EA (1988) Direct RNA sequencing techniques for work with higher plants. Plant Mol Biol Reporter 6:179-197

Hedlund BP, Staley JT (2004) Microbial endemism and biogeography. In: Bull AT (ed) Microbial diversity and bioprospecting. ASM Press, Washington, pp 225-231

Hoppert M, Holzenburg A (1998) Electron microscopy in microbiology. Bios Scientific Publ, London

Hoppert M, Flies C, Pohl W, Günzl B, Schneider J (2004a) Colonization strategies of lithobiontic organisms on carbonate rocks. Environ Geol 46:4212-4428

Hoppert M, Reimer R, Kemmling A, Schröder A, Günzl B, Heinken T (2004b) Structure and reactivity of a biological soil crust from a xeric sandy soil in Central Europe. Geomicrobiol J 21:183-191

Hughes SJ (1976) Sooty molds. Mycologia 68:693-820

Jasalavich CA, Ostrofsky A, Jellison J (2000) Detection and identification of decay fungi in spruce wood by restriction fragment length polymorphism analysis of amplified genes encoding rRNA. Appl Environ Microbiol 66:4725-4734

Jeon S, Bunge J, Leslin C, Stoeck T, Hong S, Epstein SS (2008) Environmental rRNA inventories miss over half of protistan diversity. BMC Microbiol 8:222

Kämper M, Vetterkind S, Berker R, Hoppert M (2004) Methods for in situ detection and characterization of extracellular polymers in biofilms by electron microscopy. J Microbiol Meth 57:55-64

Karsten U, Friedl T, Schumann R, Hoyer K, Lembcke S (2005) Mycosporine-like amino acids and phylogenies in green algae: Prasiola and its relatives from the Trebouxiophyceae (Chlorophyta). J Phycol 41:557-566

Kemmling A, Kämper M, Flies C, Schieweck O, Hoppert M (2004) Biofilms and extracellular matrices on geomaterials. Environ Geol 46:429-435

Korytowski W, Sarna T (1990) Bleaching of melanin pigments. J Biol Chem 265:12410-12416

Leppard GG (1995) The characterization of algal and microbial mucilages and their aggregates in aquatic ecosystems. Sci Total Environ 165:103-131

Macedo MF, Miller AZ, Dionisio A, Saiz-Jimenez C (2009) Biodiversity of cyanobacteria and green algae on monuments in the Mediterranean Basin: an overview. Microbiology 155:3476-3490

Martiny JB, Bohannan BJ, Brown JH, Colwell RK, Fuhrman JA, Green JL, Horner-Devine MC, Kane M, Krumins JA, Kuske CR, Morin PJ, Naeem S, Ovreås L, Reysenbach AL, Smith VH, Staley JT (2006) Microbial biogeography: putting microorganisms on the map. Nat Rev Microbiol 4:102-112

Mattox K, Bold HC (1962) Phycological studies III. The taxonomy of certain ulotricacean algae. Univ Texas Publ No 6222, Austin

Mehta VB, Vaidya BS (1978) Cellular and extracellular polysaccharides of the blue-green alga Nostoc. J Exp Bot 29:1423-1430

Meusnier I, Singer GAC, Landry J-F, Hickey DA, Hebert PDN, Hajibabaei M (2008) A universal DNA mini-barcode for biodiversity analysis. BMC Genomics 9:214 
Michailyuk TI (2008) Terrestrial lithophilic algae in a granite canyon of the Teteriv River (Ukraine). Biologia 63:824-830

Okuda K (2002) Structure and phylogeny of cell coverings. J Plant Res 115:283-288

Phillips AJL, Alves A, Pennycook SR, Johnston PR, Ramaley A, Akulov A, Crous PW (2008) Resolving the phylogenetic and taxonomic status of dark-spored teleomorph genera in the Botryosphaeriaceae. Persoonia 21:29-55

Polo A, Cappitelli F, Brusetti L, Principi P, Villa F, Giacomucci L, Ranalli G, Sorlini C (2010) Feasibility of removing surface deposits on stone using biological and chemical remediation methods. Microb Ecol 60:1-14

Ritz K, Young IM (2004) Interactions between soil structure and fungi. Mycologist 18:52-59

Roth J, Bendayan M, Carlemalm E, Villiger W, Garavito M (1981) Enhancement of structural preservation and immunocytochemical staining in low temperature embedded pancreatic tissue. J Histochem Cytochem 29:663-671

Samejima H, Myers J (1958) On the heterotrophic growth of Chlorella pyrenoidosa. J Gen Microbiol 18:107-117

Schlösser UG (1994) Sammlung von Algenkulturen at the University of Göttingen; catalogue of strains 1994. Bot Acta 107:113-186

Simonovicova A, Godyova M, Svec J (2004) Airborne and soil microfungi as contaminants of stone in a hypogean cemetery. Int Biodeter Biodegrad 54:7-11

Suryanarayanan TS, Ravishankar JP, Venkatesan G, Murali TS (2004) Characterization of the melanin pigment of a cosmopolitan fungal endophyte. Mycol Res 108:974-978
Sutherland IW (2001) Biofilm exopolysaccharides: a strong and sticky framework. Microbiology 147:3-9

Takeda H, Hirokawa T (1984) Studies on the cell wall of Chlorella V. Comparison of the cell wall chemical compositions in strains of Chlorella ellipsoidea. Plant Cell Physiol 25:287-295

Tien CJ, Sigee DC, White KN (2005) Characterization of surface sugars on algal cells with fluorescein isothiocyanate-conjugated lectins. Protoplasma 225:225-233

Tsuneda S, Aikawa H, Hayashi H, Yuasa A, Hirata A (2003) Extracellular polymeric substances responsible for bacterial adhesion onto solid surface. FEMS Microbiol Lett 223:287-292

Wainright M, Ali TA, Barakh F (1993) A review of the role of oligotrophic microorganisms in biodeterioration. Int Biodeter Biodegrad 31:1-13

Warscheid T, Braams J (2000) Biodeterioration of stone: a review. Int Biodeter Biodegrad 46:343-368

White TJ, Bruns T, Lee S, Talylor J (1990) Amplification and direct sequencing of fungal ribosomal RNA genes for phylogenetics. PCR protocols: a guide to methods and applications, pp 315-322

Wollenzien U, de Hog GS, Krumbein W, Uijthof JMJ (1997) Sarcinomyces petricola, a new microcolonial fungus from marble in the Mediterranean basin. Antonie van Leeuwenhoek 71:281-288

Zuo R, Kus E, Mansfeld F, Wood TK (2005) The importance of live biofilms in corrosion protection. Corros Sci 47:279-287 